University of Nebraska - Lincoln

DigitalCommons@University of Nebraska - Lincoln

USDA National Wildlife Research Center - Staff Publications
U.S. Department of Agriculture: Animal and Plant Health Inspection Service

2012

\title{
Synergistic stressors and the dilemma of conservation in a multivariate world: a case study in Allegheny woodrats
}

T. J. Smyser

Purdue University, Timothy.J.Smyser@aphis.usda.gov

S. A. Johnson

Indiana Department of Natural Resources

L. Kristen Page

Wheaton College, Kristen.Page@wheaton.edu

Olin Eugene Rhodes Jr.

Purdue University, rhodes@srel.uga.edu

Follow this and additional works at: https://digitalcommons.unl.edu/icwdm_usdanwrc

Part of the Life Sciences Commons

Smyser, T. J.; Johnson, S. A.; Page, L. Kristen; and Rhodes, Olin Eugene Jr., "Synergistic stressors and the dilemma of conservation in a multivariate world: a case study in Allegheny woodrats" (2012). USDA National Wildlife Research Center - Staff Publications. 1195.

https://digitalcommons.unl.edu/icwdm_usdanwrc/1195

This Article is brought to you for free and open access by the U.S. Department of Agriculture: Animal and Plant Health Inspection Service at DigitalCommons@University of Nebraska - Lincoln. It has been accepted for inclusion in USDA National Wildlife Research Center - Staff Publications by an authorized administrator of DigitalCommons@University of Nebraska - Lincoln. 


\title{
Synergistic stressors and the dilemma of conservation in a multivariate world: a case study in Allegheny woodrats
}

\author{
T. J. Smyser ${ }^{1}$, S. A. Johnson ${ }^{2}$, L. K. Page ${ }^{3}$ \& O. E. Rhodes, Jr ${ }^{1 *}$ \\ 1 Department of Forestry and Natural Resources, Purdue University, West Lafayette, IN, USA \\ 2 Wildlife Diversity Section, Indiana Department of Natural Resources, Bloomington, IN, USA \\ 3 Biology Department, Wheaton College, Wheaton, IL, USA
}

\section{Keywords}

Allegheny woodrat; Baylisascaris procyonis; genetic isolation; habitat fragmentation; hard mast; Neotoma magister; population decline; raccoon roundworm.

\section{Correspondence \\ Timothy J. Smyser, Department of Forestry and Natural Resources, Purdue University, 715 W. State Street, West Lafayette, IN 47907, USA. Email: tjsmyser@purdue.edu \\ ${ }^{*}$ Current address: USDA-APHIS-WS, National Wildlife Research Center, Fort Collins, CO, USA.}

Editor: Karina Acevedo-Whitehouse Associate Editor: Mariana Morando

Received 3 May 2011; accepted 14 October 2011

doi:10.1111/j.1469-1795.2011.00505.x

\begin{abstract}
Contemporary patterns of species decline frequently stem from multiple, synergistic pressures, which much like the genetic concept of lethal equivalents, must be interpreted in sum rather than as independent deleterious entities. For example, the recent, range-wide decline of the Allegheny woodrat (Neotoma magister) is likely a result of numerous, minor, human-mediated stressors including habitat fragmentation and disruption of metapopulation dynamics, reduced hard mast availability associated with the functional extirpation of American chestnut (Castanea dentata) and recent shifts in forest composition, and expansion of a humanadapted species, the raccoon (Procyon lotor) and the parasites it carries (Baylisascaris procyonis). To evaluate the assertion that range-wide woodrat declines have been caused by a concatenate of stressors, we used principal component (PC) analysis to identify latent relationships among a suite of biological and ecological factors (reflecting those stressors listed above) and evaluated PC scores relative to the three conservation states of woodrat populations in Indiana (stable, diminished and extirpated). Populations of differing conservation states segregated along each of the three retained PCs, providing support for the assertion that a combination of stressors has contributed to the range-wide decline of woodrat metapopulations, although intriguingly, independent stressors appeared to cause the decline of individual populations. These results suggest specific, minimal site attributes must be met for each of the habitat attributes evaluated to support stable woodrat populations. Our findings further suggest that variation in relative pressures exerted by individual stressors across populations will require site-specific management actions if woodrat populations are to be recovered throughout their range. Our case study of Indiana woodrats exemplifies the first step in identifying site-specific causes for species' declines, necessary to guide subsequent management and recovery actions when a combination of interwoven factors likely are contributing to metapopulation degeneration.
\end{abstract}

\section{Introduction}

Contemporary patterns of population decline and species endangerment seldom are caused by single factors functioning independently; more often, declines reflect the cumulative response to multiple pressures (Lawler et al., 2002; Laurance \& Useche, 2009). Frequently, such pressures function synergistically as the net negative effect for population persistence exceeds the sum of factors operating in isolation (Brook, Sodhi \& Bradshaw, 2008; Laurance \& Useche, 2009). Accordingly, conservation biologists often face the difficult challenge of mitigating a complex array of interwoven threats in the recovery of declining species (Lawler et al., 2002).
Reflecting this complexity, the rapid decline of Allegheny woodrat (Neotoma magister) populations has been characterized as a 'perplexing wildlife mystery' (Hicks, 1989). Amid widespread declines and localized extirpations, biologists have failed to identify a single primary factor threatening woodrat populations. Rather, a unique confluence of numerous, minor, human-mediated stressors has emerged as contributing to the collapse of Allegheny woodrat populations (LoGiudice, 2006).

With local extirpations first noted in New York in the late 1970s (Hicks, 1989), the decline of Allegheny woodrats progressed rapidly throughout the species' range. Allegheny woodrats are now listed as a species of conservation concern in 10 of the 14 states in which they occur (Wright, 2008). 


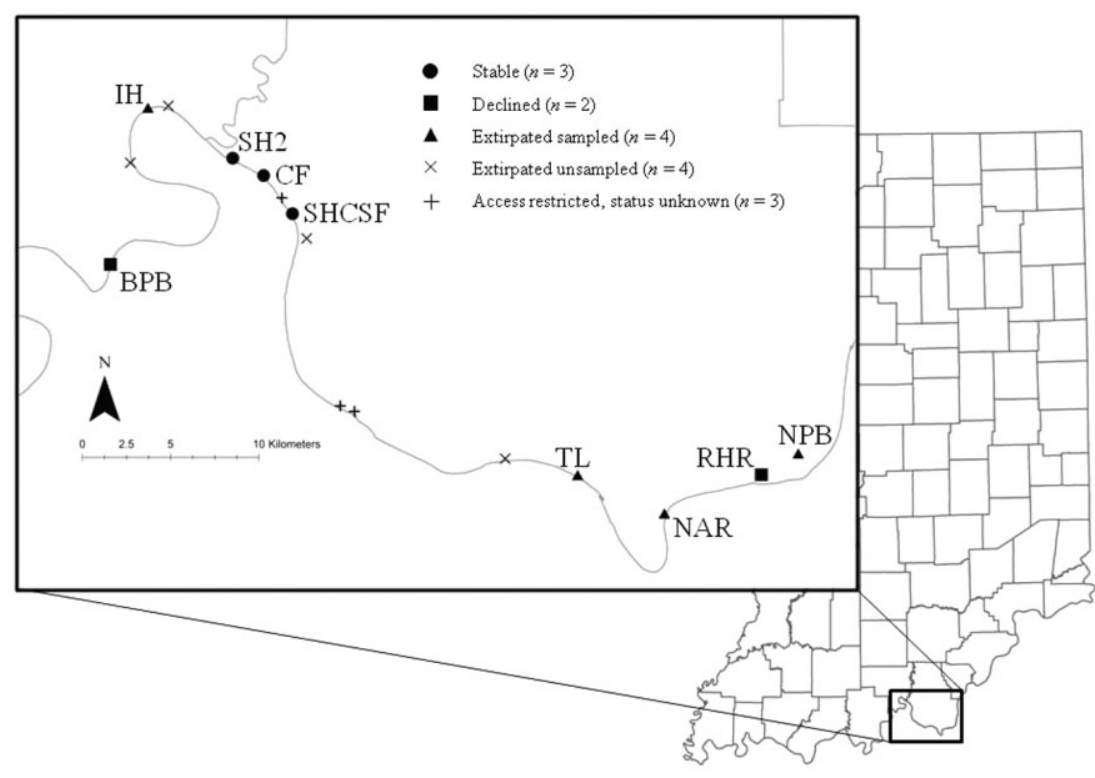

Figure 1 Spatial distribution of stable, diminished and extirpated Allegheny woodrat (Neotoma magister) populations evaluated in southern Indiana. Stable (SH2, Shelter House 2; CF, Cold Friday, SHCSF, South HarrisonCrawford Bluff), diminished (BPB, Bull's Point Bluff; RHR, Rabbit Hash Ridge) and extirpated $(\mathrm{IH}$, Indian Hollow; $\mathrm{TL}$, Tobacco Landing; NAR, Narrows; NPB, Noe's Park Bluff).
LoGiudice (2006) hypothesized that the interrelated, synergistic factors of habitat fragmentation, reduced hard mast food availability, and increased mortality associated with parasitic raccoon roundworm (Baylisascaris procyonis) infection have negatively impacted Allegheny woodrat populations. Additionally, limited dispersal capacity and small effective population sizes make Allegheny woodrat populations highly susceptible to loss of diversity through genetic drift (Smyser \& Rhodes, 2008). This array of seemingly minor stressors, when operating synergistically, can lead to rapid extirpation of local populations, although the relative pressure exerted by these stressors varies throughout the species' range.

Allegheny woodrats within Indiana have decreased precipitously over the past 30 years with mark-recapture population indices suggesting abundance declined by $>50 \%$ from the early 1980s to 2006 (Mengak et al., 2008). Through this period of decline, the relative contribution of the various stressors was unknown, and impacts appeared to be site specific as some populations remained stable whereas others declined sharply or were extirpated. Accordingly, our objective was to evaluate differences in habitat attributes across stable, diminished and extirpated populations in Indiana to test LoGiudice's (2006) hypothesis that a combination of factors is responsible for woodrat population collapse. Specifically, we assessed levels of habitat fragmentation, hard mast production potential, roundworm exposure risk, abiotic attributes indicative of local carrying capacity and potential for genetic connectivity, to elucidate how these factors may interact synergistically to contribute to local population dynamics.

\section{Study area}

Initial efforts to characterize the distribution of Allegheny woodrats within Indiana identified 16 disjunct populations
(Cudmore, 1983, Madej \& Johnson, 1993; Fig. 1). We selected a subset $(n=9)$ of these populations, which included all known extant populations $(n=5)$ and the four of the eight extirpated populations that possessed the best abiotic habitat suitability based on our assessment of rock characteristics. The seven unsampled sites included the four extirpated populations with marginal abiotic habitat (i.e. rock characteristics) and three populations on private property to which access was denied. All populations were associated with limestone and sandstone cliff habitats bordering the Ohio River in Harrison and Crawford counties in southern Indiana, representing a geographic range of 41 linear $\mathrm{km}$ along 76 river $\mathrm{km}$ (Fig. 1). These rocky habitats defined an abrupt transition between upland forests above and forested flood plain below cliff lines. Vegetation communities associated with the base of cliffs and flood plains were dominated by sugar maple (Acer saccharum) with equal components of white ash (Fraxinus americana), chinkapin oak (Quercus muehlenbergii) and eastern red bud (Cercis canadensis; Cudmore, 1983). Vegetation communities above cliffs were composed of eastern red cedar (Juniperus virginiana), white oak ( $Q$. alba), northern red oak (Q. rubra), pignut hickory (Carya glabra), shagbark hickory (C. ovata) and sugar maple (Cudmore, 1983). Within cliff lines, we defined specific sites as a linear reach of habitat between the two most distant suitable den sites, based on a history of woodrat occupancy (unpubl. data).

Woodrat populations in the following three sites were considered stable as abundance in 2006 was $>50 \%$ of the maximum number of individuals captured (Table 1): Shelter House 2 (SH2), Cold Friday Bluff (CF), South HarrisonCrawford Bluff (SHCSF). The following two sites supported diminished populations as 2006 abundance was substantially lower than previously documented $(<50 \%$ of the maximum number of individuals, Table 1): Bull's Point Bluff (BPB) and Rabbit Hash Ridge (RHR). The remaining 
Table 1 Habitat attributes and principal component (PC) scores associated with stable, diminished and extirpated Allegheny woodrat populations in southern Indiana

\begin{tabular}{|c|c|c|c|c|c|c|c|c|c|c|c|c|c|}
\hline Site ${ }^{a}$ & Status $^{b}$ & Max & $2006 \%{ }^{d}$ & For $^{\mathrm{e}}$ & Anthro ${ }^{f}$ & Mast_Dg & Mast_Div'h & Bpr_expose & Connect ${ }^{j}$ & $\mathrm{~K}^{\mathrm{k}}$ & $P C 1^{\prime}$ & PC2 & PC3 \\
\hline$\overline{\mathrm{IH}}$ & Extirpated & 15 & $0\left(-^{m}\right)$ & 44.58 & 11.26 & 61.43 & 1.57 & 0.08 & 157.34 & 13 & 0.14 & -0.17 & 0.15 \\
\hline NAR & Extirpated & 7 & $0(-)$ & 70.71 & 6.93 & 88.27 & 1.45 & 1.20 & 1.26 & 5 & 0.62 & 1.47 & -1.57 \\
\hline NPB & Extirpated & 7 & $0(-)$ & 38.38 & 25.13 & 56.31 & 1.73 & 2.58 & 6.50 & 5 & 2.37 & -0.40 & 0.47 \\
\hline TL & Extirpated & 12 & $8(1)$ & 68.19 & 2.73 & 48.73 & 1.47 & 0.00 & 1.66 & 12 & -0.92 & -0.80 & -1.15 \\
\hline BPB & Diminished & 32 & 19 (6) & 58.59 & 4.22 & 56.90 & 1.89 & 0.46 & 1.39 & 23 & -0.35 & -0.60 & 1.54 \\
\hline RHR & Diminished & 20 & $35(7)$ & 48.70 & 14.79 & 49.85 & 1.44 & 0.14 & 6.85 & 14 & -0.17 & -1.25 & -0.80 \\
\hline $\mathrm{CF}$ & Stable & 26 & $65(17)$ & 67.34 & 0.00 & 64.06 & 1.74 & 0.04 & 40.56 & 17 & -0.66 & 0.06 & 0.44 \\
\hline $\mathrm{SH} 2$ & Stable & 22 & $68(15)$ & 58.47 & 0.37 & 66.31 & 1.65 & 0.28 & 19.81 & 16 & -0.43 & -0.06 & 0.05 \\
\hline SHCSF & Stable & 41 & $100(41)$ & 75.43 & 0.97 & 82.55 & 1.68 & 0.08 & 239.99 & 22 & -0.61 & 1.75 & 0.86 \\
\hline
\end{tabular}

alncorporated populations include BPB, Bull's Point Bluff; CF, Cold Friday; IH, Indian Hollow; NAR, Narrows; NPB, Noe's Park Bluff; RHR, Rabbit Hash Ridge; SH2, Shelter House 2; and SHCSF, South Harrison-Crawford Bluff; TL, Tobacco Landing.

bPopulations in which $\leq 1$ individual was captured were considered extirpated, extant populations in which 2006 abundance was $<50 \%$ of the maximum number captured were considered diminished, and populations in which 2006 abundance was $>50 \%$ of the maximum number captured were considered stable.

cMaximum number of unique individuals captured over all trapping periods (1982-2009).

dNumber of unique individuals captured in 2006 (in bracket) expressed as a per cent of the maximum number of individuals captured in the population.

ePer cent of area within a 1-km buffer of woodrat habitats in forest cover (forest and wetland forest) based on 2001 Landsat TM imagery. ${ }^{t}$ Per cent of the area within a 1-km buffer of woodrat habitats in anthropogenic land use (high and low density urban and agriculture) based on 2001 Landsat TM imagery.

${ }^{9}$ Density per ha of mast-producing tree species $>25 \mathrm{~cm}$ dbh.

hShannon-Wiener Index of diversity for mast-producing tree species $>25 \mathrm{~cm}$ dbh.

'Density per ha of raccoon roundworm infective raccoon latrines.

iProximity index values $\times 10^{-7}$ for woodrat habitats as a function of the Euclidean distance to all other woodrat habitats within Indiana.

kMaximum number of unique adult woodrats captured during population monitoring surveys conducted from 1982 to 2009.

'Principal component scores by population.

mPopulations previously identified as extirpated were not monitored in 2006.

four sites were considered extirpated because no woodrats were captured during population monitoring efforts [Indian Hollow (IH), Narrows (NAR) and Noe's Park Bluff (NPB)]. We also considered Tobacco Landing (TL) extirpated because by 2005 , the population had become functionally extirpated, reduced to only one aged female captured across consecutive annual surveys with no evidence that she had reproduced recently (Table 1).

\section{Methods}

\section{Habitat fragmentation}

We used the 2001 Landsat TM imagery with $30-\mathrm{m} \times 30-\mathrm{m}$ resolution to characterize landscape composition within a $1-\mathrm{km}$ buffer $(3 \times$ the diameter of a male's home range selected to include all likely daily movements; Castleberry et al., 2001) surrounding each site. Buffers were truncated at the Ohio River because it represented a formidable barrier for woodrat movement. We restricted our analysis to two disparate habitat fragmentation metrics. The first metric was per cent forest, taken as an index of landscape integrity. Secondarily, we quantified per cent anthropogenic (high and low density urban and agriculture) land cover given the potential for these land-use types to precipitate increased competition with habitat generalists for hard mast resources, increased great horned owl (Bubo virginianus) predation pressure and increased roundworm exposure (Balcom \& Yahner, 1996; Hassinger, Butchkoski \& Diefenbach, 2008). Given that Allegheny woodrats appear to be more sensitive to the exacerbation of population pressures associated with anthropogenic land use than habitat fragmentation explicitly (Balcom \& Yahner, 1996; Castleberry et al., 2001), we assumed the per cent herbaceous grasslands (the second most common cover type within this landscape) would be neutral for the conservation state of woodrat populations. Therefore, we did not include herbaceous grassland cover as a variable in our analysis. These three land uses comprised approximately $97 \%$ of the examined landscape (across all populations forest $=73.8 \%$, grassland $=12.3 \%$, anthropogenic $=10.5 \%$, unpubl. data).

\section{Hard mast density and diversity}

We conducted overstory composition surveys in summer 2007 to identify differences among sites in density and diversity of hard mast-producing trees. We used a 10-basal area factor prism (Forestry Suppliers, Jackson, MS, USA) to define a series of variable circular plots along transects spaced at $200-\mathrm{m}$ intervals and oriented perpendicularly to the dominant bearing of the cliff line. Above the cliff, we placed the first plot adjacent to the rim with subsequent 
plots placed 40 and $100 \mathrm{~m}$ from the initial plot. Below, the first plot was placed as close to the base of the cliff as topography would allow with subsequent plots also placed 40 and $100 \mathrm{~m}$ from the initial plot, as the width of the flood plain would allow.

We identified all trees in plots to species and measured their diameter at breast height. For each site, we calculated density per ha of mast-producing trees (trees $>25 \mathrm{~cm}$ in diameter; Greenberg, 2000) defining the following as mastproducing species: white oak, chinkapin oak, chestnut oak (Quercus prinus), burr oak (Q. macrocarpa), northern red oak, black oak (Q. velutina), scarlet oak (Q. coccinea), pignut hickory, shagbark hickory, mockernut hickory (Carya tomentosa), bitternut hickory (C. cordiformis), black walnut (Juglans nigra), American beech (Fagus grandifolia), black cherry (Prunus serotina), hackberry (Celtis occidentalis), Kentucky coffeetree (Gymnocladus dioicus) and persimmon (Diospyros virginiana). Additionally, we calculated the Shannon-Wiener Diversity Index (H', Krebs, 1994) of mastproducing trees to reflect the greater stability of mast availability with increased species diversity.

\section{Raccoon roundworm exposure}

We conducted raccoon (Procyon lotor) latrine strip transect surveys to characterize raccoon roundworm exposure risk for each site. Surveys were conducted in autumn 2006 and 2007 to coincide with the annual peak in roundworm egg production (Kazacos, 2001) and period in which woodrats actively cache food items for overwinter subsistence and are therefore most at risk for roundworm infection (Castleberry \& Castleberry, 2008). Survey and fecal analysis methods have been described previously (Smyser, Page \& Rhodes, 2010).

We used number of latrines detected within the area searched to estimate site-specific density of raccoon latrines. Latrines encountered opportunistically outside strip transects but associated with a given site were excluded from density estimates but were included in estimates of latrine size and roundworm prevalence. Average latrine size was determined by dividing total number of discernable unique defecation events (scats) by number of latrines sampled. We estimated roundworm prevalence as number of scats containing roundworm eggs relative to total number of scats evaluated. We combined site-specific measures of latrine density, average latrine size and prevalence of roundworm to estimate density of infective latrines.

\section{Proximity to adjacent woodrat populations}

Connectivity among Allegheny woodrat populations reflects patterns of genetic isolation by distance (Castleberry et al., 2002; Smyser \& Rhodes, 2008). Therefore, we used a proximity index to quantify the potential for individuals to move among sites and the effect such movement would have for recolonization and ameliorating genetic drift. We defined the proximity index as

$$
\sum_{i=1}^{n} \frac{1}{\left(d_{i j}\right)^{2}}
$$

in which $d$ represents the Euclidean distance between site $i$ and the proximate edges to all other sites $j$ (adapted from Gustafson \& Parker, 1994), incorporating all study sites and populations excluded from this study that supported woodrats as recently as 1982 (Cudmore, 1983; Madej \& Johnson, 1993).

\section{Abiotic carrying capacity}

Allegheny woodrats establish dens within complex rock structures, which they defend from conspecifics. Beyond abundance of suitable den sites, populations may be further limited by agonistic behavior among woodrats, introducing spatial constraints in the number of territories a site can support (Peles \& Wright, 2008). Given the relationship between population size and the threat of extirpation posed by demographic stochasticity, we used the maximum number of unique adults captured during any single population monitoring effort conducted between 1982 and 2009 as a measure of a site's carrying capacity. Population monitoring efforts consisted of standard live-trapping techniques for Allegheny woodrats in which single door live traps (Tomahawk Live Traps, Hazelhurst, WI, USA) baited with sliced apples were maintained for two nights; detailed methods have been described previously (Johnson, 2002).

\section{Statistical analysis}

We conducted a principal component analysis with varimax rotation (SAS v. 9.2; SAS Institute, Cary, NC, USA) to characterize relationships among habitat attributes and to reduce these habitat attributes to a smaller number of latent factors. Varimax rotation was used to facilitate interpretability of principal components (PCs). We used the KaiserGuttman rule (PCs with eigenvalues $\geq 1$ are retained) to identify the number of PCs to be retained for interpretation.

We plotted PC scores to qualitatively evaluate the relationship between the status of woodrat sites (stable, diminished, extirpated) and each PC.

\section{Results}

\section{Habitat fragmentation}

Forest cover within a $1-\mathrm{km}$ buffer surrounding woodrat sites ranged from $38 \%$ at NPB to $75 \%$ at SHCSF (Table 1 ). Anthropogenic land use ranged from $0 \%$ at $\mathrm{CF}$ to $25 \%$ at NPB (Table 1).

\section{Hard mast density and diversity}

We surveyed an average of 21.2 forest plots within each site ranging from nine at NAR to 35 at CF and RHR; differences in number of plots were attributable to variation in 
Table 2 Attributes of raccoon roundworm contamination at Allegheny woodrat habitats in southern Indiana based on raccoon latrine surveys conducted throughout the surrounding forests in fall 2006 and fall 2007

\begin{tabular}{|c|c|c|c|c|c|c|c|c|c|}
\hline Site $^{a}$ & $\begin{array}{l}\text { ha } \\
\text { search }^{\text {b }}\end{array}$ & $\begin{array}{l}\text { Latrines } \\
\left(\mathrm{w} / \mathrm{i}_{\mathrm{i}} \text { transects }\right)^{c}\end{array}$ & $\begin{array}{l}\text { Lat } \\
\text { density }^{d}\end{array}$ & $\begin{array}{l}\text { Total } \\
\text { latrines }\end{array}$ & $\begin{array}{l}\text { Total } \\
\text { scats }{ }^{f}\end{array}$ & $\begin{array}{l}(+) \\
\text { scats }^{9}\end{array}$ & $\begin{array}{l}\text { Scat } \\
\text { prev }\end{array}$ & $\begin{array}{l}\text { scats/ } \\
\text { lati }\end{array}$ & $\begin{array}{l}\text { (+) lat } \\
\text { den }\end{array}$ \\
\hline$\overline{\mathrm{IH}}$ & 8.67 & 39 & 4.50 & 60 & 87 & 1 & 0.01 & 1.45 & 0.07 \\
\hline$N A R^{k}$ & 13.48 & 79 & 5.86 & 78 & 154 & 16 & 0.10 & 1.97 & 1.20 \\
\hline$N^{N} B^{k}$ & 5.93 & 56 & 9.45 & 66 & 169 & 18 & 0.11 & 2.56 & 2.58 \\
\hline $\mathrm{TL}$ & 6.70 & 23 & 3.43 & 107 & 133 & 0 & 0.00 & 1.24 & 0.00 \\
\hline $\mathrm{BPB}^{\mathrm{k}}$ & 11.72 & 48 & 4.10 & 62 & 80 & 7 & 0.09 & 1.29 & 0.46 \\
\hline $\mathrm{RHR}^{\mathrm{k}}$ & 31.23 & 83 & 2.66 & 114 & 140 & 6 & 0.04 & 1.23 & 0.14 \\
\hline$C F$ & 26.80 & 36 & 1.34 & 65 & 93 & 2 & 0.02 & 1.43 & 0.04 \\
\hline $\mathrm{SH} 2$ & 11.92 & 57 & 4.78 & 51 & 103 & 3 & 0.03 & 2.02 & 0.28 \\
\hline SHCSF & 23.35 & 60 & 2.57 & 68 & 82 & 2 & 0.02 & 1.21 & 0.08 \\
\hline
\end{tabular}

alncorporated populations include BPB, Bull's Point Bluff; CF, Cold Friday; IH, Indian Hollow; NAR, Narrows; NPB, Noe's Park Bluff; RHR, Rabbit Hash Ridge; SH2, Shelter House 2; SHCSF, South Harrison-Crawford Bluff; and TL, Tobacco Landing.

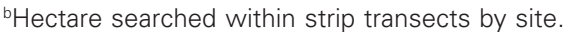

'Number of latrines detected within strip transects.

dDensity of latrines within sites (number of latrines/ha searched)

eTotal number of latrines sampled within sites including latrines encountered within strip transects and those encountered opportunistically.

'Total number of discernibly unique defecation events (scats) across all latrines.

${ }^{9}$ Number of positive scats defined by the detection of $\geq 1$ raccoon roundworm eggs with fecal flotation.

hPrevalence of positive scats (number of positive scats/number of scats evaluated).

'Number of discernibly unique defecation events (scats)/number of latrines sampled.

iDensity of positive latrines incorporating the attributes latrine density, average scats per latrine and frequency of raccoon roundworm eggs within scats.

kSmyser et al., 2010.

length of cliff habitat and flood plain width. Density of mast-producing trees ranged from 49 (TL) to 88 (NAR) trees per ha (Table 1). The Shannon-Wiener diversity $\left(H^{\prime}\right)$ index varied across sites from 1.44 at RHR to 1.89 at BPB (Table 1).

\section{Raccoon roundworm exposure}

Across all sites, we searched 140 ha in strip transects and detected 481 latrines. An additional 190 latrines were encountered opportunistically. Collectively, these 671 latrines were comprised of 1041 scats (Table 2). Within sites, we evaluated between 80 (BPB) and 169 scats (NPB), collected from 51 (SH2) to 114 (RHR) latrines with average latrine size varying from 1.21 (SHCSF) to 2.56 (NPB; Table 2). Observed density ranged from 1.34 (CF) to 9.45 (NPB) latrines per ha (Table 2). Observed roundworm prevalence ranged from $0 \%$ at TL to $11 \%$ at NPB (Table 2). Density of infective latrines ranged from 0 to 2.58 per ha at TL and NPB, respectively (Table 1).

\section{Proximity to adjacent woodrat populations}

The site with the highest connectivity was SHCSF with a proximity value of $239.99 \times 10^{-7}$. The most isolated site was NAR with a proximity value of $1.26 \times 10^{-7}$ (Table 1 ).

\section{Abiotic carrying capacity}

The number of annual surveys conducted at each site ranged from five at IH to nine at BPB, RHR, TL, CF and SHCSF.
Annual survey effort varied across sites because monitoring was discontinued once no woodrats were captured and the site was assumed to be extirpated. Maximum number of adults captured ranged from five at NAR and NPB to 23 at BPB. With the exception of $\mathrm{IH}$, the maximum number of adults was observed during surveys conducted by the authors. The maximum number of adults at IH was from Cudmore (1983; employing similar methods) as this population became extirpated before the statewide monitoring program was initiated in 1991.

\section{Statistical analysis}

Principal component analysis with a varimax rotation identified three principal components with eigenvalues $\geq 1$. The first three PCs captured $84 \%$ of the variation among the seven habitat attributes with $38 \%$ of the variation partitioned to PC1, 25\% to PC2 and 21\% to PC3 (Table 3). The first $\mathrm{PC}$ reflected difference among sites in land use and raccoon roundworm exposure risk (Table 3). Differences in maximum number of adults also influenced PC1 (Table 3 ). Values for PC1 ranged from -0.92 at TL (extirpated) to 2.37 at NPB (extirpated), with increasing PC1 scores representing decreasing habitat quality (Table 1). The second PC reflected differences in density of mast-producing trees, and to a lesser extent, per cent forest cover and proximity to adjacent populations (Table 3 ). Values for PC2 ranged from -1.25 at RHR (diminished) to 1.75 at SHCSF (stable) with increasing values associated with improving habitat quality (Table 1). PC3 was dominated by diversity of mastproducing species with a lesser contribution from maximum 
Table 3 Principal component (PC) eigenvalues and PC loadings for seven habitat attributes evaluated for stable, diminished and extirpated Allegheny woodrat populations in southern Indiana

\begin{tabular}{lccc}
\hline & PC1 & PC2 & PC3 \\
\hline Variance explained & 2.63 & 1.76 & 1.48 \\
Per cent variance & $38 \%$ & $25 \%$ & $21 \%$ \\
Factor Pattern & & & \\
For $^{\mathrm{a}}$ & -0.64 & 0.62 & -0.15 \\
Anthro $^{\mathrm{b}}$ & 0.87 & -0.35 & -0.07 \\
Mast_D $^{\mathrm{c}}$ & 0.03 & 0.97 & -0.07 \\
Mast_Div $^{\mathrm{d}}$ & 0.09 & 0.01 & 0.93 \\
Bpr_expose $^{\mathrm{e}}$ & 0.95 & 0.06 & 0.01 \\
Connect $^{f}$ & -0.21 & 0.56 & 0.36 \\
$\mathrm{~K}^{9}$ & -0.71 & 0.02 & 0.67 \\
\hline
\end{tabular}

aPer cent of the area within a $1-\mathrm{km}$ buffer of woodrat habitats in forest (forest and wetland forest) cover based on 2001 Landsat TM imagery.

${ }^{b}$ Per cent of the area within a $1-\mathrm{km}$ buffer of woodrat habitats in anthropogenic land use (high and low density urban and agriculture) cover based on 2001 Landsat TM imagery.

'Density per ha of mast-producing tree species $>25 \mathrm{~cm}$ dbh.

dShannon-Wiener Index of diversity for mast-producing tree species $>25 \mathrm{~cm}$ dbh.

eDensity per ha of raccoon roundworm infective raccoon latrines.

fProximity index values for woodrat habitats as a function of the Euclidean distance to all other woodrat habitats within Indiana.

9Maximum number of unique adult woodrats captured during population monitoring surveys conducted from 1982 to 2009.

number of adults (Table 3). Values for PC3 ranged from -1.57 at NAR (extirpated) to 1.54 at BPB (diminished) with increasing PC3 scores representing increasing habitat quality (Table 1).

Plots between PC1 and PC2 revealed a general gradient from extirpated on the right to stable populations on the left (PC1 axis, Fig. 2a). The extirpated site of TL was a notable outlier to this general trend with the most favorable PC1 score (Table 1). Along the PC2 axis, we observed a positive relationship between the conservation state of a woodrat population and PC2 scores with stable sites having three out of the top four PC2 scores (Fig. 2a and b). The extirpated site NAR was a notable outlier from this general trend with the second highest PC2 score. The plot of PC1 versus PC3 revealed a general trend in which stable woodrat populations had favorable values for both PC1 (low) and PC3 (high; Fig. 2b). The diminished population of BPB also clustered with this group, exhibiting a high PC3 score. In the plot between PC2 and PC3, stable populations had favorable (high) values for both PCs, although one diminished population (BPB) and two extirpated populations (IH and NPB) fell in among the stable populations (Fig. 2c). The extirpated site NAR had a high PC2 score but the lowest PC3 score, whereas the remaining sites TL (extirpated) and RHR (diminished) population had low values for both PCs (Fig. 2c).
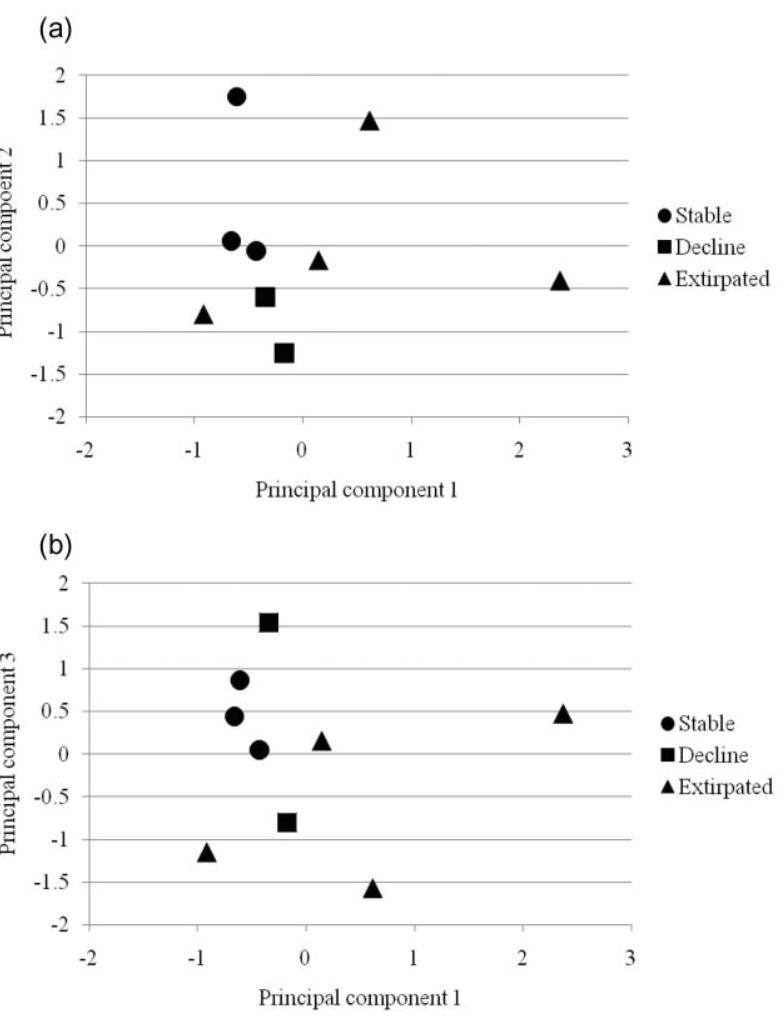

(c)

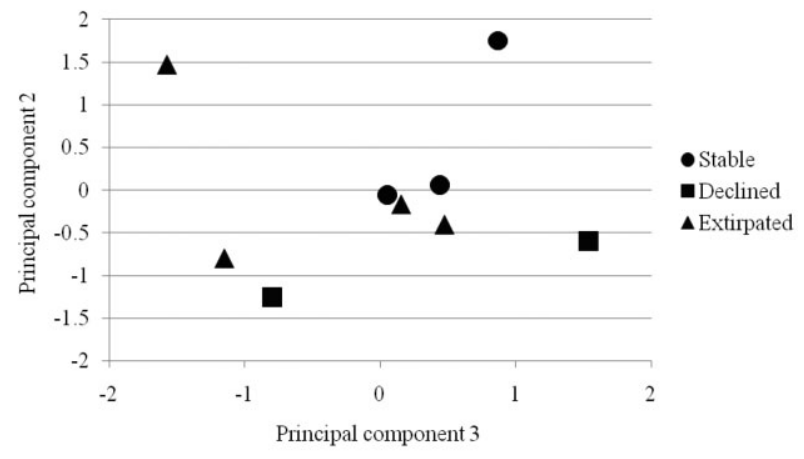

Figure 2 Scatter plots of principal components (PCs) based on a compilation of seven habitat attributes (\% forest, $\%$ anthropogenic land use, hard mast tree density, hard mast tree diversity, raccoon roundworm exposure and proximity to adjacent habitat patches) assessed at stable, diminished and extirpated Allegheny woodrat (Neotoma magister) habitats in southern Indiana. Plots reflect PC1 (land-use composition and raccoon roundworm exposure) plotted against PC2 (hard mast density; a), PC1 plotted against PC3 (hard mast density; b) and PC2 plotted against PC3 (c).

\section{Discussion}

Our exploration of latent interactions among woodrat habitat attributes in Indiana revealed differences among stable, diminished and extirpated woodrat populations. In a general context, our identification of an array of factors contributing to local population dynamics supports the 
assertion that a synergism of minor stressors is responsible for the collapse of woodrat populations. Alternatively, examination of specific diminished and extirpated populations revealed multiple cases in which unique, independent stressors were associated with the decline of the population. In sum, our analysis revealed a multifaceted set of minimum habitat attributes in which deficiencies in any one of these attributes appears sufficient to threaten the persistence of the local population.

Examination of habitat attributes within an exploratory principle component context effectively identified the interrelated nature of stressors negatively impacting Allegheny woodrats populations. The association between roundworm exposure and anthropogenic land use captured in $\mathrm{PC} 1$ reflects increases in raccoon densities with forest fragmentation and concomitant increases in roundworm prevalence due to elevated intraspecific contact rates (Gompper \& Wright, 2005; Wright \& Gompper, 2005). Many Indiana woodrat populations were associated with low levels of anthropogenic land use and roundworm exposure (Table 1). Alternatively, the density of infective raccoon latrines at NPB was greater than nine times higher than among stable populations (SH2, CF and SHCSF). Additionally, roundworm prevalence at NPB (11\%) approached levels observed in New York and New Jersey (17-24\%; LoGiudice, 2003) where roundworm-related mortality was responsible for the failure of woodrat reintroductions. NPB exemplifies a population in which levels of anthropogenic land use and concomitant roundworm exposure make the site unsuitable for woodrat occupancy in the absence of management intervention (Page et al., 2011).

Maximum number of adults, our proxy for abiotic carrying capacity, also contributed strongly to PC1. If maximum number of adults truly reflected carrying capacity, there would be no reason to predict a priori that carrying capacity would be related to land use and raccoon roundworm exposure. Alternatively, maximum number of adults was based on population surveys conducted over the past 30 years, a period of rapid woodrat decline. Landsat TM imagery collected between 1985 and 2001 suggests general land-use composition of woodrat sites in Indiana has remained largely unchanged over this period of decline with per cent forest cover within a $1-\mathrm{km}$ buffer surrounding woodrat habitats declining from $76.6 \%$ to $73.8 \%$ and per cent anthropogenic land use increasing from 8.9 to $10.5 \%$ (unpubl. data). Rather than representing abiotic carrying capacity, the contribution of maximum number of adults to PC1 suggests the deleterious effects of habitat fragmentation may have already impacted local woodrat abundance by the time monitoring efforts were initiated.

Allegheny woodrats depend upon cached hard mast for subsistence through the winter (Castleberry \& Castleberry, 2008) with the availability of such resources having important implications for overwinter survival (Castleberry et al., 2001), fecundity (McClure, 1987) and population dynamics (Mengak \& Castleberry, 2008). With the extirpation of the American chestnut (Castanea dentata) and loss of the species' annually dependable mast resource, woodrats have come to rely upon the stochastic availability of acorns to stock winter caches. Oaks demonstrate regional synchrony in mast production within species, and to a lesser extent, subgenera, but acorn production may be asynchronous across species (Koenig \& Knops, 1998; Greenberg, 2000; Greenberg \& Parresol, 2002). Also, acorn production varies across years (Koenig et al., 1994; Greenberg, 2000). Therefore, to minimize potential for complete mast failure, it is essential that forests surrounding woodrat habitats support a diversity of oak and other masting species (Greenberg, 2000; Greenberg \& Parresol, 2002; Hassinger et al., 2008).

In the absence of a dominant and dependable masting species such as American chestnut, PC2 and PC3 portrayed two distinct elements of hard mast availability: mast tree density and diversity, and it is necessary to evaluate these two attributes together (Fig. 2c) to characterize site suitability. Among the populations evaluated, the presence of a cluster of sites composed of stable (SHCSF, CF, SH2), declined (BPB) and extirpated populations (IH, NPB) with neutral or positive values for both PC2 and PC3 suggests that these sites all support a sufficient density and diversity of mast-producing trees to sustain woodrat populations. Alternatively, NAR (extirpated) had the highest mast density and yet the second lowest mast diversity. Members of the red oak subgenera (northern red, black and scarlet oak) comprise nearly $70 \%$ of mast-producing species at NAR (unpubl. data). Correlation in mast production within the red oak subgenera makes the woodrat population at NAR vulnerable to mast failures (Greenberg \& Parresol, 2002). Other populations including RHR and TL, with low levels for both diversity and density of mast-producing trees, may be vulnerable, particularly during low mast years.

Loss of genetic diversity has been hypothesized as a cause for the decline of Allegheny woodrats in Indiana (Smyser \& Rhodes, 2008), but the proximity index, a measure of genetic isolation, was not incorporated in a meaningful way into any of the retained PCs. The utility of the proximity index for describing functional connectivity was limited by a failure to incorporate the declining trend in habitat occupancy that typifies this and other nonequilibrium metapopulations and spatial variation in the quality of potential source sites. To illustrate, IH had high proximity values despite the extirpation of surrounding woodrat populations over the period of examination (1982-2009) due to habitat destruction and degradation (unpubl. data). Additionally, RHR (diminished) and NPB (extirpated) had intermediate values for connectivity (6.85 and 6.50, respectively), which were driven by the close proximity of the sites to one another (separated by $<1.3 \mathrm{~km}$ ), despite the fact that anthropogenic land use and roundworm exposure make NPB unsuitable for woodrat occupancy. A lack of genetic connectivity likely limits the long-term viability of other Indiana woodrat populations. With low proximity values and nearest neighbor distances, which greatly exceed the typical dispersal capacity of woodrats, BPB (diminished) was susceptible to the unmitigated effects of genetic drift and onset of inbreeding depression as would have been the extirpated sites NAR and TL (Castleberry et al., 2002; Wood, 2008). 
In evaluating an array of habitat attributes across stable, diminished and extirpated populations, we have gained greater understanding of how habitat fragmentation, genetic isolation, hard mast availability and roundworm exposure synergistically interact in Allegheny woodrat population dynamics. Through the dichotomy observed between stable populations and diminished and extirpated populations, we have begun to quantify minimum levels of these attributes necessary for the persistence of woodrat populations. Examination of specific instances of decline or extirpation clearly revealed that sites lacking in any one of these habitat attributes are unable to support woodrat populations over the long term. Our case study of Indiana woodrats exemplifies the first step in identifying site-specific causes for species' declines, necessary to guide subsequent management and recovery actions when a combination of interwoven factors likely are contributing to metapopulation degeneration. The multifaceted nature of the extrinsic pressures and the variability of their impacts across small spatial scales will present challenges for the recovery of Allegheny woodrats throughout the species' range and likely will require site-specific management action.

\section{Acknowledgments}

We would like to thank C. Hudson, A. Holbrook, H. Walker, B. Geboy, N. Bergmeier, J. Faller, Z. Bagley, J. Utz and B. Haslick for field assistance and M. Downey, P. Girgis, B. Griffin, K. Kellner and S. McCord for laboratory assistance. Thank you to W. Cudmore for making raw data from initial woodrat distribution surveys available. We are grateful for financial and logistical support provided by Indiana Department of Natural Resources (State Wildlife Grant T07R02), Purdue University, Wheaton College Alumni Association and The Nature Conservancy.

\section{References}

Balcom, B.J. \& Yahner, R.H. (1996). Microhabitat and landscape characteristics associated with the threatened Allegheny woodrat. Conserv. Biol. 10, 515-525.

Brook, B.W., Sodhi, N.S. \& Bradshaw, C.J.A. (2008). Synergies among extinction drivers under global change.

Trends Ecol. Evol. 96, 453-460.

Castleberry, N.L. \& Castleberry, S.B. (2008). Food selection and caching behavior. In The Allegheny woodrat: ecology, conservation and management of a declining species: 93-106. Peles, J.D. \& Wright, J. (Eds). New York: Springer Publishing Company.

Castleberry, S.B., Ford, W.M., Wood, P.B., Castleberry, N.L. \& Mengak, M.T. (2001). Movements of Allegheny woodrats in relation to timber harvesting. J. Wildl. Mgmt. 65, 148-156.

Castleberry, S.B., King, T.L., Wood, P.B. \& Ford, W.M. (2002). Microsatellite DNA analysis of population structure in Allegheny woodrats (Neotoma magister). J. Mammal. 83, 1058-1070.
Cudmore, W.W. (1983). The distribution and ecology of the eastern woodrat, Neotoma floridana, in Indiana. PhD thesis, Indiana State University.

Gompper, M.E. \& Wright, A.N. (2005). Altered prevalence of raccoon roundworm (Baylisascaris procyonis) owing to manipulated contact rates of hosts. J. Zool. 266, 215219.

Greenberg, C.H. (2000). Individual variation in acorn production by five species of southern Appalachian oaks. For. Ecol. Manage. 132, 199-210.

Greenberg, C.H. \& Parresol, B.R. (2002). Dynamics of acorn production by five species of southern Appalachian oaks. In Oak forest ecosystems: ecology and management for wildlife: 149-172. McShea, W.J. \& Healy, W.M. (Eds). Baltimore: The John Hopkins University Press.

Gustafson, E.J. \& Parker, G.R. (1994). Using an index of habitat patch proximity for landscape design. Landsc. Urban Plan. 29, 117-130.

Hassinger, J.D., Butchkoski, C.M. \& Diefenbach, D.R. (2008). Managing surface rock communities for Neotoma magister. In The Allegheny woodrat: ecology, conservation and management of a declining species: 133-152. Peles, J.D. \& Wright, J. (Eds). New York: Springer Publishing Company.

Hicks, A.P. (1989). Whatever happened to the Allegheny woodrat? Conservationist 43, 34-38.

Johnson, S.A. (2002). Reassessment of the Allegheny woodrat (Neotoma magister) in Indiana. Proc. Indiana Acad. Sci. 111, 56-66.

Kazacos, K.R. (2001). Baylisascaris procyonis and related species. In Parasitic diseases of wild mammals: 301-341. Samuel, W.M., Pybus, M.J. \& Kocan, A.A. (Eds). Ames: Iowa State University Press.

Koenig, W.D. \& Knops, J.M.H. (1998). Scale of mastseeding and tree-ring growth. Nature 396, 225-226.

Koenig, W.D., Mumme, R.L., Carmen, W.J. \& Stanback, M.T. (1994). Acorn production by oaks in central coastal California: variation within and among years. Ecology 75, 99-109.

Krebs, C.J. (1994). Ecological methodology. 2nd edn. Menlo Park: Addison Wesley Longman, Inc.

Laurance, W.F. \& Useche, D.C. (2009). Environmental synergisms and extinctions of tropical species. Conserv. Biol. 23, 1427-1437.

Lawler, J.J., Campbell, S.P., Guerry, A.D. \& Kolozsvary, M.B. (2002). The scope and treatment of threats in endangered species recovery plans. Ecol. Appl. 12, 663667.

LoGiudice, K. (2003). Trophically transmitted parasites and the conservation of small populations: raccoon roundworm and the imperiled Allegheny woodrat. Conserv. Biol. 17, 258-266.

LoGiudice, K. (2006). Toward a synthetic view of extinction: a history lesson from a North American rodent. Bioscience 56, 687-693. 
Madej, R.F. \& Johnson, S.A. (1993). Allegheny Woodrat Monitoring Program 1993: an assessment of the distribution of the Allegheny woodrat in Indiana. Bloomington, IN: Indiana Department of Natural Resources.

McClure, P.A. (1987). The energetics of reproduction and life histories of cricetine rodents (Neotoma floridana and Sigmodon hispidus). Symp. Zool. Soc. Lond. 57, 241-258.

Mengak, M.T., Butchkoski, C.M., Feller, D.J. \& Johnson, S.A. (2008). Lessons from long-term monitoring of woodrat populations. In The Allegheny woodrat: Ecology, Conservation and Management of a Declining Species: 109-132. Peles, J.D. \& Wright, J. (Eds). New York: Springer Publishing Company.

Mengak, M.T. \& Castleberry, S.B. (2008). Influence of acorn mast on Allegheny woodrat population trends in Virginia. Northeast Nat. 15, 475-484.

Page, L.K., Beasley, J.C., Olson, Z.H., Smyser, T.J., Downey, M., Kellner, K.F., McCord, S.E., Egan, T.S., II \& Rhodes, O.E. Jr (2011). Reducing Baylisascaris procyonis roundworm larvae in raccoon latrines. Emerg. Infect. Dis. 17, 90-93.

Peles, J.D. \& Wright, J. (2008). Den use behavior of Allegheny woodrats inhabiting rock outcrops in Pennsylvania. In The Allegheny woodrat: ecology, conservation and management of a declining species: 75-91. Peles, J.D. \& Wright, J. (Eds). New York: Springer Publishing Company.

Smyser, T.J., Page, L.K. \& Rhodes, O.E., Jr (2010). Optimization of raccoon latrine surveys for quantifying Baylisascaris procyonis exposure. J. Wildl. Dis. 46, 929-933.

Smyser, T.J. \& Rhodes, O.E. Jr (2008). Genetic diversity of woodrats: implications for conservation. In The Allegheny woodrat: ecology, conservation and management of a declining species: 153-167. Peles, J.D. \& Wright, J. (Eds). New York: Springer Publishing Company.

Wood, P. (2008). Woodrat population dynamics and movement patterns. In The Allegheny woodrat: ecology, conservation and management of a declining species: 45-62. Peles, J.D. \& Wright, J. (Eds). New York: Springer Publishing Company.

Wright, A.N. \& Gompper, M.E. (2005). Altered parasite assemblages in raccoons in response to manipulated resource availability. Oecologia 144, 148-156.

Wright, J. (2008). History and current status of the Allegheny woodrat. In The Allegheny woodrat: ecology, conservation and management of a declining species: 3-22. Peles, J.D. \& Wright, J. (Eds). New York: Springer Publishing Company. 